\title{
CRITICAL SUCCESS FACTORS IN INSURANCE COMPANIES
}

\author{
Jasmina Selimović ${ }^{*}$ \\ Danijela Martinovic ${ }^{* * *}$ \\ Džana Hurko***
}

Received: 15. 12. 2018

Review

Accepted: 28. 4. 2020

UDC 005.336.1:368.03

DOI https://doi.org/10.30924/mjcmi.25.1.12

368.03(497.6)

\begin{abstract}
The topic of this research are critical success factors (CSFs) with a focus on factors that constitute the basis for the success of insurance companies. There are no critical success factors common to all enterprises, all areas and all activities. In insurance companies, key performance indicators primarily depend on the service quality and the level of customer satisfaction. In contemporary business conditions, the relevance of the service has been increasingly important. Therefore, the concept named 5P is suggested, standing for purpose, pride, partnership, protection and personalization, as these five factors define the requirements that must be met, if the insurer's service is to be perceived to be of highquality, achieve client satisfaction and build client loyalty. The paper presents a research into the perception of insurance service and factors of insurance quality in the Federation of Bosnia and Herzegovina $(\mathrm{FBiH})^{l}$. Research results correspond to the 5P concept and reveal the security factor as the most important factor for the insured. A fast and efficient payment of claims, the attitude of the salespeople toward the insured, described in terms of respectful and knowledgea-
\end{abstract}

ble staff, as well as the clarity of promotion and the availability of insurance service also ranked high.

Key words: critical success factors, insurance companies, $5 P$ concept

\section{INTRODUCTION}

Critical success factors (CSFs) are very complex and have been insufficiently studied. There are no critical success factors common to all enterprises, all areas and all activities. Critical success factors vary from one industry to another, from one market to another. Success is sometimes a subjective perception of decision makers or the perception of delivered value as it is assessed by the customer or end user of a service. It is very hard to generalize. Consequently, an attempt to analyse and define the critical success factors should take into account the specific characteristics of each particular

\footnotetext{
* Jasmina Selimović, PhD, University of Sarajevo, School of Economics and Business, Bosnia and Herzegovina, Phone: +387 33275 906, Fax: +387 33275 994, E-mail: jasmina.selimovic@efsa.unsa.ba

** Danijela Martinović, PhD, University of Sarajevo, School of Economics and Business, Bosnia and Herzegovina, Phone: +387 61 219539, Fax: +387 33 275994, E-mail: danijela.martinovic@efsa.unsa.ba

*** Džana Hurko, MSc, Uniqa osiguranje d.d. Sarajevo, Bosnia and Herzegovina, Phone: +387 61928 066, E-mail: dzana.hurko@gmail.com

1 Since the country, Bosnia and Herzegovina consists of two entites (Federation of Bosnia and Herzegovina and Republic of Srpska), the research was conducted in one of them, in Federation of Bosnia and Herzegovina.
} 


\section{Journal of Contemporary Management Issues}

area - production and services, industry, actual market and relations within it (existing and potential competition, final users' requirements and preferences, technological achievements, etc.) - and affinities of decision-makers themselves, their perceptions, experiences and beliefs related to the critical success factors. An analysis of strengths, weaknesses and potentials of an actual company also contributes to determining the critical success factors. A number of critical success factors emerge as the result of taking into account all the factors and specific characteristics of the industry/ market/company. Some are more general than others, others are more specific for the area and market where companies do business; some are a result of objective, expert assessment and statistical and mathematical analysis while others are a result of decision-makers' subjective assessments and experience. However, regardless of their diversity, it can be concluded that they are dynamic by nature. Therefore, for companies and their management to survive and succeed, it is of crucial importance to define the truly critical success factors. Scholars agree that it is necessary to focus on a small number of truly critical factors, so as not to waste resources and capacities.

The main goal of the paper is to identify and explain the most important factors that influence the success of insurance companies considering the service quality concept described as the 5P concept, which supports Maslow's hierarchy of needs as explained by Zealley et al (2018). The success of insurance can be described using different approaches, but in this paper the authors focused on insurers' view. No similar research has been conducted on a small transitional economy insurance sector in Bosnia and Herzegovina.

When analyzing the research results and examining the characteristics of the insurance market of a small transitional economy, it can be concluded that typical success factors cannot be the only indicators of business quality and success in insurance. In order to systematically analyze the success of insurance companies, other economic factors as well as insurance company's financial indicators are included in the following step of the research.

To determine the critical success factors in insurance companies, the survey was conducted in the period from January to April 2018 and included current and potential users of various types of insurance on the territory of the Federation of Bosnia and Herzegovina. A total of 217 individuals took part in the survey.

The paper is divided into four sections. The rest of the papers is organized as follows. The problem and the main idea are presented in the first section. Since the concept of success can be analyzed using different approaches the second section presents various scientific contributions to this issue. The focus is on the concept that will be used in the paper. The special attention is devoted to the factors relevant for the insurance sector. It is important to mention that both parties in insurance contract are analysed: the insured and the insurer. Factors relating to the companies' point of view are a part of the quality of insurer's service construct. The other group of factors related to the client's perspective is a part of the client satisfaction construct. The last section of the paper focuses on the results of the survey conducted and on the discussion.

\section{THE CONCEPT OF CRITICAL SUCCESS FACTORS}

The concept of critical success factors was first defined in the second half of the $20^{\text {th }}$ century, in papers by D. R. Daniel (1961), John F. Rockart and Christine V. Bullen (1979; 1981). Rockart and Bullen 
(1981, p. 7) were the first to define the critical success factors as "the limited number of areas in which satisfactory results will ensure successful competitive performance for the individual, department or organization". Critical success factors are the few key areas where things must go right for the business to flourish and for the manager's goals to be attained. Boynton and Zmud (1984,. p.19) stated that critical success factors are "managerial or organizational areas that deserve special and continued attention to allow the achievement of significant/ high performance". They are the crucial basis for the success of current activities, as well as for achieving success in the future. These are the factors an organization must focus on to be successful. Sanvido et al. (1992, p. 92) defined critical success factors as the "aspects of business identified as critical/unavoidable to achieve and manage the goals that illustrate success. They are typically found in the areas such as production processes, employees' organizational and personal skills, functions, techniques and technologies." Critical success factors help to forecast the project success rather than merely serving to survive (Sanvido et al., 1992; Ghosh et al., 2001), i.e., they are of critical importance for the success of a project. (Toor \& Ogunlana, 2009). Grunert and Ellegaard (1992,. p.14) defined the critical success factors as "skills or resources that a company invests in and that explain, by observing the market where the company operates, most visible differences in the perceived value and/or relative costs."

Critical factors include skills, knowledge and resources which differentiate one company from another, i.e., which provide the company with the competitive advantage and are the basis of excellence. Competitive advantage and company's market success are based on customers'/ final users' assessment and preferences, i.e., on the perceived value of a product or service. In this respect, a great significance is also attached to the price, i.e., the relative cost incurred in the production of a product or service. The degree to which a company will create low-cost value for customers will depend on the company's skills, knowledge and resources. Therefore, Grunert and Ellegaard (1992, p.15.) define critical success factors as "skills or resources that explain most visible differences in the perceived value and/or relative costs, taking into account market specifics.' Consequently, the research is not focused on and is not limited only to the key skills and resources of business functions and management's internal aspect and plans; rather, critical success factors also include and take into account both performance determinants and market requirements, competitors' performance, as well as customers' perception and preferences. The described integrated approach to the concept of critical success factors illustrates the complexity of the process of their determination.

Rockart (1979) described the five sources of critical success factors, which in turn result in four kinds of critical success factors: Industry CSFs - which result from the distinctive characteristics of the industry; Strategy CSFs - resulting from the enterprise's chosen competitive strategy; Environmental CSFs - resulting from economic or technological changes; and Temporal CSFs - which are a result of internal organizational needs and changes.

\section{CRITICAL SUCCESS FACTORS IN THE INSURANCE COMPANIES}

Insurance companies are a form of financial institutions, which are typically the largest institutional investors. According to their core activity, insurance companies collect funds from the public (legal and natural persons) who, upon paying the premium 


\section{Journal of Contemporary Management Issues}

become the insured (policyholders). In return for the collected funds, insurance companies, as their insurers, provide protection and pecuniary indemnification in the case of the materialization of a risk-insured event, which is precisely defined in the insurance contract and insurance policy. Based on these characteristics of insurance activity, it can be concluded that the product of the insurance industry is a service, i.e., that it is a service industry. Insurance services have typical characteristics of any service, as well as some others, distinctive for the insurance industry. Indeed, the insurance service is based on trust that a potential insured person has in the insurance company.

If we observe the insurer's success, the perspective is fairly wide, and primarily depends on whether the success is assessed from the position of the insurer or from the position of the insured person. The insurer's position would definitely be more based on performance indicators that can be expressed by different kinds of indicators in the insurance company.

Depending on the activities that the insurer is involved in, it is possible to single out different success indicators, although in general one can consider the level and structure of total equity the company has at its disposal, the level and structure of the total income (particularly the collected premiums), the amount of the guarantee capital, as well as other insurer's funds. A particular attention is paid to the level and structure of technical provisions, which directly depend on the type of insurance, on the type of products of the individual group of insurance contracts and the maturity of reserve holdings, technical provisions coverage, i.e., the type and maturity structure of insurer's investments, as well as on the technical and financial business result. Besides these general indicators, the assessment of an insurer's success attaches a particular attention to special indicators, specific for individual types of insurance.

If the success is assessed from the insured person's position, the exact indicators such as those used in the previous case are not easily measurable and are difficult to describe. However, if success is observed as a process rather than the final result, the question arises as to what factors contribute to the success of an insurance company. Such consideration allows the unified identification of success factors, which can be viewed from the aspect of service provider, the insurer, and service seeker - the insured person.

The key success factors can be applied to the insurance companies, as well. The success of an insurance company should be viewed in the synergy with the service users' satisfaction and their perception of the quality of service and delivered value for money. Thus, when assessing success, it is necessary to observe all the participants in the process - the insured and the insurer and the way they interact. When defining the key insurance success factors, some authors pay more attention to the insured and others to the insurer.

The following factors are singled out as essential for the insurer's success:

- $\quad$ size, tradition and image, i.e. reputation, of the insurance company (Eccles and Vollbracht, 2006),

- its market position and success (Chuwiruch and Ussahawanitchakit, 2013; Eling and Kiesenbauer, 2012),

- the quality and ability of the management (Ranani and Arastoo, 2006; Keck et al, 1995),

- use of the modern ways of management - the need to introduce change 
management, knowledge management as well as risk management (Mitra et al, 2019; Joshi et al, 2016; Cummins, 2005),

- characteristics of the sales force, i.e., their motivation (Srivastava et al, 2020; Eesley and Adidam, 2012; Yang et al, 2011; Manna and Smith, 2004, Keck et al, 1995),

- the characteristics, i.e., the quality, number and distinctiveness of the provided services, with a focus on customization (Oduniyi et al, 2020) and customer-centric processes (Kreuzer et al, 2020), i.e., process personalization and good communication (Chuwiruch and Ussahawanitchakit, 2013). Infrastructure and processes must create new and added value for users (Roeschmann, 2018; Cata and Lee, 2006), i.e., create the value chain for all participants (Fjeldstad and Ketels, 2006). Innovation and utilization of intellectual capital contribute to the insurer's success (Rajapathirana and Hui, 2018; Shahsiah and Sepahvand, 2016; Bader, 2008).

With respect to the insured person, the insurance success requires: insurance persons' demographic characteristics (age, origin, level of education, marital status, income - Oduniyi et al, 2020; Li et al, 2007), psychological characteristics (risk aversion, e.g. Lewis, 1989) and the present experience and awareness of the usefulness of insurance (Oduniyi et al, 2020). The segmentation of the insured persons based on the above listed characteristics (Trautingen, 2018; Hamdi and Zamiri, 2016) and customization creates a loyal and satisfied user (Groesch and Steul-Fischer, 2017). A maximization of users' satisfaction is the ultimate goal of insurance (Mahlow and Wagner, 2016; Trautinger, 2018). Quality and sophisticated service, which corresponds to users' preferences, certainty of return and the level of achieved income (higher total return for policyholders), as well as a reasonable price of the insurance service, significantly contribute to the satisfaction of the insurance users (Lorson and Wagner, 2014).

A separate category of factors that affect insurance and that needs to be pointed out are macroeconomic indicators, i.e., national income, government spending on social security and inflation (Browne and Kim, 1993) and demographic characteristics that affect the overall demand for the insurance products, i.e., the number of births, population development, number of marriages (Mantis and Farmer, 1968).

In this context, critical success factors are all those factors that are necessary for the provision of a service that the clients need, i.e., all the variables that can affect the company's success measured by its financial performance. Critical factors of the insurer's success may include the quality of service offered by the insurer, the degree of clients' satisfaction and clients' loyalty (Farokhain and Sadeghi, 2011). In the first decade of this century, clients' loyalty was perceived as an important success factor; however, taking into account all the changes in the market, in the near future loyalty will be replaced with the assessment as to whether the offered service is relevant for the client (Zealley et al. 2018). Defined in this way, these elements can be perceived from both sides, by the insurer and by the insured person.

\subsection{The quality of insurer's service}

From the insured person's viewpoint, the quality of the offered service can be described by its deviation from the insured person's expectations compared to the 


\section{Journal of Contemporary Management Issues}

provided service. Thus, the larger the difference between the expected and the provided service, the lower the level of insurer's service quality.

The process of designing the service that will be offered is primarily the insurer's task, and it is necessary to take account of the insured persons' needs in the process. The insured person will choose which insurance company they can put their trust in based on both the personal perception and financial indicators. The insured person's perception is based on the information they have about the insurance company and on possible previous experience with the company. Besides, an important role is also played by the image the insurer is developing and nourishing which is, in turn, supported by a series of insurer's factors, e.g., promotion, reputation, salespeople, etc. The basic goal of each of these activities, i.e., promoting the service or its sale, should be to assure the insured person that the service offered is of high quality. These factors are relevant before the very process of buying the insurance service, and when making a decision on buying the service and choosing the insurance company.

From the moment when the insured person makes the decision to purchase the service, pays the premium and receives the insurance policy, the factors that determine success begin to change. Since the contract has been concluded, the insured person now attaches importance to the after-sales service they may need from the insurer. A particularly important element that will determine the level of service quality for the insured person during the term of the contract is the degree of nominal and actual efficiency and the effectiveness of settling claims. If the insured person's expectations do not or only negligibly deviate from the provided service, it is certain that such an insured person will perceive the service as of higher quality and that they will be interested in renewing or continuing the insurance policy with the same insurer. Care for the client near and after the expiry of the contract contributes to the insured person's feeling of trust and reliance, and, thus, increases the perception of the high quality of service provided by the insurer.

Other factors that substantially determine the service quality include the price offered for the service, i.e., insurance premium. Besides the lowest price, insured persons will pay attention to the reputation of the insurance company. However, besides the actuarial calculation of premiums, and to ensure market competitiveness and make the offered service economically acceptable for the insured persons, it is necessary to take account of the demand and competitors' prices for the same or similar service. In possible correction of prices due to lower prices by the competitors, the insurer must also pay attention to its technical result from this type of insurance. Other factors that substantially determine the insurance service quality include the distribution of service. Insurance service can be distributed in different ways, through several sales channels. The requirement that insurance policies should be available to insured persons when the need arises, at an appropriate site is important and determines the service quality.

\subsection{Client satisfaction}

Another factor that determines the insurance companies' success together with the service quality is the level of clients' satisfaction with the provided service. If client satisfaction, as a factor, is viewed chronologically, it can be observed in several stages. The availability of information the client has or can obtain from the insurer 
characterizes the first stage before a client makes the decision on buying the insurance service. An insured person can obtain information on insurance services in several ways, i.e., through various media the insurers uses to promote their services.

When making a decision on buying an insurance service or choosing an insurance company, the primary criterion in economies with a low standard of living may be the price of insurance service. However, a low price can be the result of non-competitive process of insurer's pricing, i.e., it can directly point to problems in solvency, which ultimately leads to the failure to honour the obligation that the insurer has toward the insured person and loss of the insured person's trust. Consequently, it is extremely important to present to the insured persons all the details of the service being offered and terms and conditions under which it is offered (insurance terms and conditions). Brokers and sales representatives in insurance companies play an extremely important role in this process. They are the employees who will gain insured persons' trust, which will in turn result in a high level of client satisfaction.

Insurer's timely and proper response during the term of the contract when it is necessary to change some elements of the contract, to provide additional clarifications or, to settle a claim directly affects insured persons' satisfaction and their decision on whether or not they will extend or renew the contract.

Besides client satisfaction, scholars pay a particular attention to client loyalty. Client loyalty typically used to be developed and maintained through various benefits or gifts that the insured persons received from the insurer. However, recently conducted research suggests that such insurer's actions do not directly lead to the increase of client loyalty. At the same time, it should be pointed out that such activities are fairly costly for the insurer. Modern business has been gradually abandoning the concept of loyalty and switching to consideration of how relevant and important a product or service is for a potential client. The typical common treatment of the elements of marketing mix no longer satisfies the increasingly demanding clients, who are not a static category.

Since the degree of service relevance is becoming increasingly important, the development of a concept named 5P is recommended (Zealley et al. 2018). This concept was developed to support the elements of Maslow's hierarchy of needs. The first element relates to the goal and objective of doing business (purpose). Clients should feel that the company, an insurance company, shares and promotes the same values as they do. Thus, the insurer's primary goal should be the security of invested resources (and consequently the client's security). The second element of this concept relates to the development of the feeling of pride that clients feel when using the services offered by the company. Insurer's good reputation will certainly significantly contribute to this feeling. The third element is the partnership between the insured person and the insurer. If clients feel and experience the insurer's commitment, their feeling of satisfaction with the service will increase. The fourth element is the degree of protection, which in insurance industry is fairly similar to the first element, and pertains to the fact that insured persons should feel secure in doing business with the insurer (secure in the context of paid premiums, as well as in the context of claims that should be paid when the insured event even materializes). The last, fifth element is service personalization. Clients, the insured persons, must feel that each insurance service offered to 


\section{Journal of Contemporary Management Issues}

them has been tailored to their needs. The last element is also the most important one in assessing the relevance of insurance service. Thus, the insurance policy should be designed to accurately correspond to the insured person, to cover the risks they are exposed to, to take account of their frequency and intensity of the potential harm, duration of exposure, age, occupation, or any other risk factor an individual insured person may be exposed to. Such policies become relevant to insured persons and directly contribute to client loyalty. At the same time, services personalized in this way provide the insurer with market advantage and price competitiveness.

Thus, the insurer's critical success factors primarily depend on the service quality and level of client satisfaction. However, having in mind the complexity of the insurance industry, the successful business of every insurer will be affected by several other elements, such as: the level of knowledge about the market they do business in and the degree of adaptability to market demands, sales channels the insurers have at their disposal, legislation and subordinate regulations, the level of financial market development, insurer's technical capacities, (non-)existence of culture and habit of buying insurance services, which pertains to voluntary insurance, etc.

\section{EMPIRICAL RESULTS}

To determine the critical success factors in insurance companies in 2018, a survey was conducted in the Federation of Bosnia and Herzegovina. The survey was conducted verbally and in writing. A total of 217 citizens took part in the survey. Demographic data relating to the respondents' gender, age, level of education, marital status, employment status and monthly income are shown in Table 1.

Table 1: Demographic data of the sample

\begin{tabular}{|c|c|c|c|c|c|c|}
\hline \multirow{2}{*}{ Gender } & \multicolumn{3}{|c|}{ Male } & \multicolumn{3}{|c|}{ Female } \\
\hline & \multicolumn{3}{|c|}{125} & \multicolumn{3}{|c|}{92} \\
\hline \multirow{2}{*}{ Age } & $18-25$ & & $6-35$ & $36-45$ & $56-65$ & $>65$ \\
\hline & 36 & & 58 & 48 & 25 & 4 \\
\hline \multirow[t]{2}{*}{ Level of education } & $\begin{array}{c}\text { Secondary } \\
\text { school or } \\
\text { lower }\end{array}$ & \multicolumn{2}{|c|}{ College-level } & Bachelor & \multicolumn{2}{|c|}{ Master or $\mathrm{PhD}$} \\
\hline & 74 & \multicolumn{2}{|r|}{22} & 98 & \multicolumn{2}{|c|}{23} \\
\hline \multirow{2}{*}{ Marital status } & Married & \multicolumn{2}{|r|}{ Single } & Divorced & \multicolumn{2}{|c|}{ Widowed } \\
\hline & 129 & \multicolumn{2}{|r|}{70} & 15 & \multicolumn{2}{|c|}{3} \\
\hline \multirow{2}{*}{ Employment status } & \multicolumn{2}{|c|}{ Employed } & \multicolumn{2}{|c|}{ Unemployed } & \multicolumn{2}{|c|}{ Retired } \\
\hline & \multicolumn{2}{|c|}{171} & \multicolumn{2}{|c|}{38} & \multicolumn{2}{|l|}{8} \\
\hline \multirow{2}{*}{$\begin{array}{c}\text { Monthly income (in } \\
\text { BAM) }\end{array}$} & $<500$ & $501-800$ & $801-1,000$ & $1,101-1,500$ & $>1,500$ & Unknown \\
\hline & 4 & 61 & 37 & 54 & 26 & 35 \\
\hline
\end{tabular}

Source: Authors 
The questionnaire consisted of 40 questions, classified in three major categories: demographic data, perception of insurance (questions 11-15), and quality of insurance (questions 28-40). Question number 40 was open-ended and required respondents to list factors/aspects of business that they believe insurance companies should improve, with the aim of increasing quality.

The section below provides an overview and interpretation of the obtained results according to the categories listed above.

\subsection{Perception of insurance}

A total of $72.35 \%$ respondents have insurance policies, while $27.65 \%$ do not. An automobile liability insurance policy is held by $60.37 \%$ of the total number of respondents, i.e., by $83.44 \%$ of all policyholders. The average number of policies is 1.83 ; one policy is held by 72 respondents, two by 96, and three or more by 119 respondents. Compulsory vehicle insurance and travel health insurance prevail. The highest percentage of respondents who have insurance $(38.22 \%)$, pay the total annual premium lower than 500 BAM, while $61.15 \%$ of policyholders pay up to 800 BAM.

Respondents, who do not have an insurance policy, listed the following reasons for not having one: lack of money $(61.67 \%)$, lack of interest in insurance (33.33\%), lack of knowledge about insurance (20\%). As many as $30 \%$ of respondents in this group listed two or more reasons for not having a policy (out of the five offered responses). A total of $13.33 \%$ respondents stated that the reason for not having an insurance policy is that they had not found a suitable offer, and the same percentage of respondents pointed out that they do not trust insurance companies.

Respondents' replies suggest that poverty and a low standard are the prevailing reasons for not having an insurance policy. Due to this fact, the compulsory vehicle insurance prevails among the insured persons as well. Reasons that follow point to the fact that insurance companies in Federation of Bosnia and Herzegovina have an inadequate marketing approach to the public (they do not analyze the market, requirements and desires of potential insured persons and insufficiently promote their services). Educating the public on the need and significance of insurance and adjusting the offer to users' needs must be the focus of insurance companies.

The existence of a certain negative perception among the respondents related to the insurance companies' relationship toward (potential) insured persons, clarity of services and their prices was partially confirmed in responses to questions on perception of insurance.

Table 2: Perception of insurance

\begin{tabular}{|c|c|c|c|c|c|c|c|c|c|c|c|c|}
\hline \multicolumn{13}{|c|}{ Responses } \\
\hline \multirow[t]{2}{*}{ Question } & \multicolumn{2}{|c|}{$\begin{array}{l}\text { Strongly } \\
\text { disagree }\end{array}$} & \multicolumn{2}{|c|}{ Disagree } & \multicolumn{2}{|c|}{ Neutral } & \multicolumn{2}{|c|}{ Agree } & \multicolumn{2}{|c|}{$\begin{array}{l}\text { Strongly } \\
\text { agree }\end{array}$} & \multicolumn{2}{|l|}{ Total } \\
\hline & $\mathrm{N}$ & $\%$ & $\mathrm{~N}$ & $\%$ & $\mathrm{~N}$ & $\%$ & $\mathrm{~N}$ & $\%$ & $\mathrm{~N}$ & $\%$ & $\mathrm{~N}$ & $\%$ \\
\hline $\begin{array}{l}\text { Insurance } \\
\text { companies are } \\
\text { institutions that } \\
\text { cheat people. }\end{array}$ & 63 & 29.03 & 47 & 21.66 & 72 & 33.18 & 29 & 13.36 & 6 & 2.77 & 217 & 100.00 \\
\hline
\end{tabular}


Journal of Contemporary Management Issues

\begin{tabular}{|c|c|c|c|c|c|c|c|c|c|c|c|c|}
\hline \multicolumn{13}{|c|}{ Responses } \\
\hline \multirow[t]{2}{*}{ Question } & \multicolumn{2}{|c|}{$\begin{array}{l}\text { Strongly } \\
\text { disagree }\end{array}$} & \multicolumn{2}{|c|}{ Disagree } & \multicolumn{2}{|c|}{ Neutral } & \multicolumn{2}{|c|}{ Agree } & \multicolumn{2}{|c|}{$\begin{array}{l}\text { Strongly } \\
\text { agree }\end{array}$} & \multicolumn{2}{|l|}{ Total } \\
\hline & $\mathrm{N}$ & $\%$ & $\mathrm{~N}$ & $\%$ & $\mathrm{~N}$ & $\%$ & $\mathrm{~N}$ & $\%$ & $\mathrm{~N}$ & $\%$ & $\mathrm{~N}$ & $\%$ \\
\hline $\begin{array}{l}\text { Insurance } \\
\text { companies do } \\
\text { not have a good } \\
\text { relationship } \\
\text { toward insured } \\
\text { persons. }\end{array}$ & 38 & 17.51 & 53 & 24.42 & 53 & 24.43 & 59 & 27.19 & 14 & 6.45 & 217 & 100.00 \\
\hline $\begin{array}{l}\text { Insurance services } \\
\text { offered are } \\
\text { incomprehensible. }\end{array}$ & 39 & 17.97 & 43 & 19.82 & 31 & 14.29 & 78 & 35.94 & 26 & 11.98 & 217 & 100.00 \\
\hline $\begin{array}{l}\text { Insurance services } \\
\text { are expensive. }\end{array}$ & 27 & 12.44 & 36 & 16.59 & 45 & 20.74 & 85 & 39.17 & 24 & 11.06 & 217 & 100.00 \\
\hline $\begin{array}{l}\text { Insurance services } \\
\text { are unnecessary in } \\
\text { daily life. }\end{array}$ & 57 & 26.27 & 89 & 41.01 & 46 & 21.20 & 20 & 9.22 & 5 & 2.30 & 217 & 100.00 \\
\hline
\end{tabular}

\section{Source: Authors}

The statement that insurance companies are institutions that cheat people was rejected by $50.69 \%$ of respondents, a total of $33.18 \%$ was neutral, while $16.13 \%$ of the respondents agreed with the statement. A certain degree of population's distrust of insurance companies is obvious. Commitment to clients, care for them, a high level of promptness in settling claims and their payment, restore trust in insurance. Professionalism and fair approach are factors that insurers must continuously work on.

A total of $33.64 \%$ of the respondents believe that insurance companies do not have a good relationship with the insured persons, $24.43 \%$ were undecided while $41.93 \%$ of the respondents rejected this statement. A negative perception of the insurance companies' relationship toward insured persons may result from poor experiences by previous users.

A total of $47.92 \%$ of the respondents agree that insurance services offered are incomprehensible, $14.29 \%$ could not decide, while $37.79 \%$ of the respondents disagree.
Education in the area of financial literacy is necessary. Salespeople must have sufficient knowledge and patience to explain all the necessary elements of insurance to users.

A total of $50.23 \%$ of the respondents agree with the statement that insurance services are expensive, $20.74 \%$ of them are neutral while $29.03 \%$ disagree. It could be assumed that insurance services are expensive for the citizens of Federation of Bosnia and Herzegovina due to people's low standard of living and a great number of the unemployed.

A total of $11.52 \%$ of the respondents believe that insurance services are unnecessary in daily life, $21.20 \%$ are neutral while $67.28 \%$ of the respondents disagree. These data are favourable for insurance companies and suggests the awareness of the need for the existence of insurance services.

\subsection{Quality of insurance}

According to the survey results, a total of $72.35 \%$ of the respondents use insurance services, while $27.65 \%$ do not use them. 
Out of those who use insurance services, $59.87 \%$ of the insured are satisfied while as many as $40.13 \%$ of insurance users are not satisfied. A total of $90.48 \%$ of the respondents who expressed dissatisfaction circled one response as the reason for it, $7.93 \%$ of the respondents circled two responses, and $1.59 \%$ of respondents circled three responses.
In response to the question if you would recommend your insurance company to others, $61.78 \%$ claimed they would, while $38.22 \%$ that they would not. The data reveal that the percentage of those who would recommend their insurance company is higher than that of those who are satisfied. Survey results pertaining to questions 28 to 39 , which examined the quality of insurance, are presented in Table 3.

Table 3: Quality of insurance

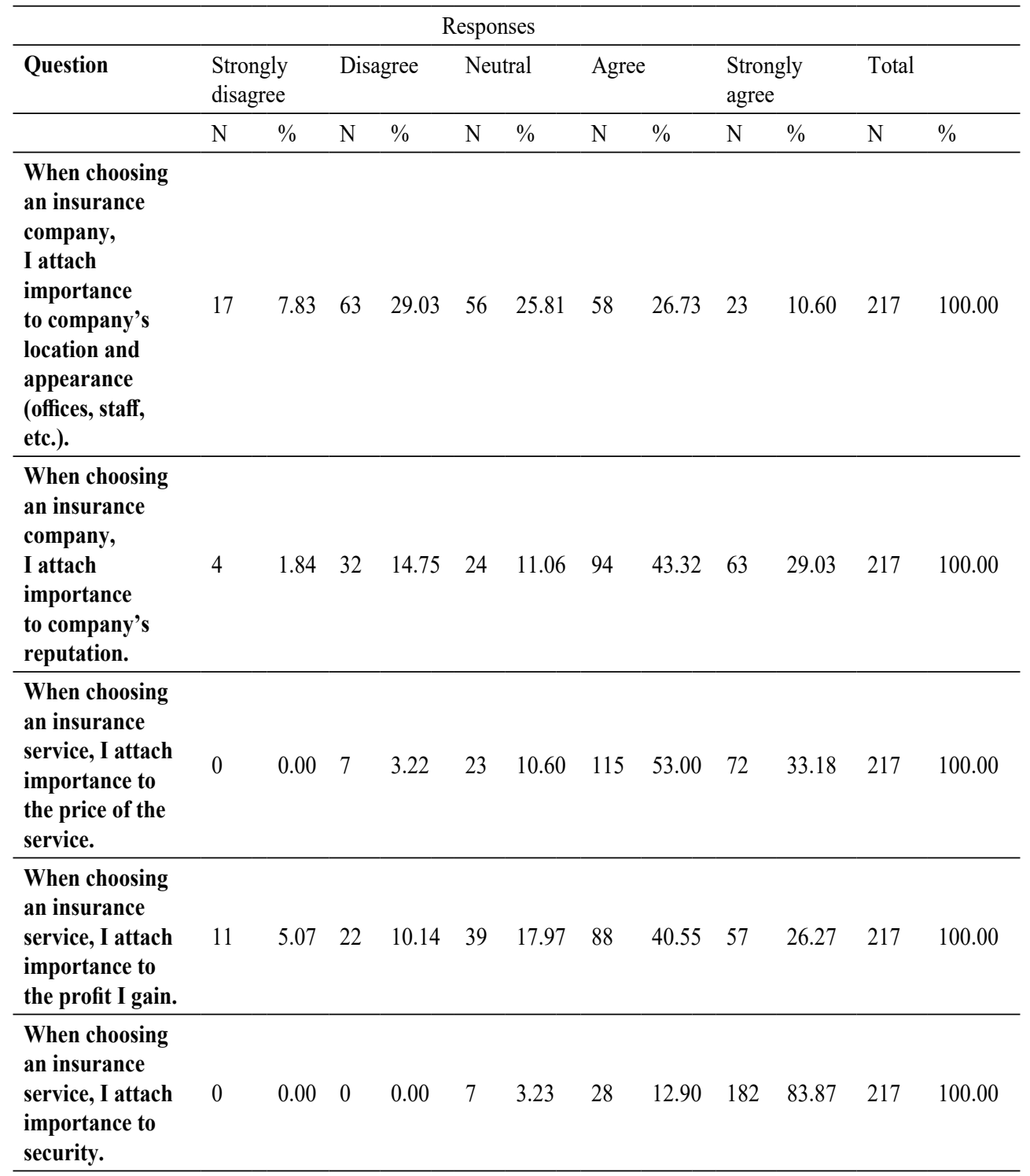


Journal of Contemporary Management Issues

\begin{tabular}{|c|c|c|c|c|c|c|c|c|c|c|c|c|}
\hline \multirow{3}{*}{ Question } & \multicolumn{10}{|c|}{ Responses } & & \\
\hline & \multicolumn{2}{|c|}{$\begin{array}{l}\text { Strongly } \\
\text { disagree }\end{array}$} & \multicolumn{2}{|c|}{ Disagree } & \multicolumn{2}{|c|}{ Neutral } & \multicolumn{2}{|c|}{ Agree } & \multicolumn{2}{|c|}{$\begin{array}{l}\text { Strongly } \\
\text { agree }\end{array}$} & \multicolumn{2}{|c|}{ Total } \\
\hline & $\mathrm{N}$ & $\%$ & $\mathrm{~N}$ & $\%$ & $\mathrm{~N}$ & $\%$ & $\mathrm{~N}$ & $\%$ & $\mathrm{~N}$ & $\%$ & $\mathrm{~N}$ & $\%$ \\
\hline $\begin{array}{l}\text { The promotion } \\
\text { of insurance } \\
\text { services should } \\
\text { be clear and } \\
\text { good. }\end{array}$ & 0 & 0.00 & 0 & 0.00 & 12 & 5.53 & 71 & 32.72 & 134 & 61.75 & 217 & 100.00 \\
\hline $\begin{array}{l}\text { Insurance } \\
\text { companies } \\
\text { should treat } \\
\text { clients with } \\
\text { respect. }\end{array}$ & 0 & 0.00 & 0 & 0.00 & 6 & 2.76 & 36 & 16.59 & 175 & 80.65 & 217 & 100.00 \\
\hline $\begin{array}{l}\text { Insurance } \\
\text { companies } \\
\text { should settle } \\
\text { and pay claims } \\
\text { quickly and } \\
\text { efficiently. }\end{array}$ & 0 & 0.00 & 0 & 0.00 & 8 & 3.69 & 31 & 14.28 & 178 & 82.03 & 217 & 100.00 \\
\hline $\begin{array}{l}\text { Insurance } \\
\text { services should } \\
\text { be easily } \\
\text { accessible. }\end{array}$ & 0 & 0.00 & 0 & 0.00 & 15 & 6.91 & 116 & 53.46 & 86 & 39.63 & 217 & 100.00 \\
\hline $\begin{array}{l}\text { Insurers' } \\
\text { salespeople } \\
\text { should always } \\
\text { be well informed } \\
\text { and provide clear } \\
\text { answers to all my } \\
\text { questions. }\end{array}$ & 0 & 0.00 & 0 & 0.00 & 5 & 2.30 & 49 & 22.58 & 163 & 75.12 & 217 & 100.00 \\
\hline $\begin{array}{l}\text { I am loyal to } \\
\text { my insurance } \\
\text { company. }\end{array}$ & 11 & 5.07 & 43 & 19.81 & 71 & 32.72 & 33 & 15.21 & 59 & 27.19 & 217 & 100.00 \\
\hline $\begin{array}{l}\text { I feel more } \\
\text { secure when } \\
\text { I have an } \\
\text { insurance policy. }\end{array}$ & 9 & 4.15 & 45 & 20.74 & 40 & 18.43 & 70 & 32.26 & 53 & 24.42 & 217 & 100.00 \\
\hline
\end{tabular}

Source: Authors

For the service quality to be rated as high, the respondents believed that it is necessary that: insurers' salespeople are always well-informed and provide clear answers to all the questions $(97.7 \%$ of the respondents), insurance companies should treat clients with respect $(97.24 \%)$, the promotion of insurance services should be clear and good (94.47\% of the respondents), and the services must be easily accessible $(93.03 \%$ of the respondents). Essentially, when choosing an insurance service, the respondents attached importance to security (a total of $96.77 \%$ of the respondents agreed 
with the statement), speed and efficiency in settling and paying claims $(96.31 \%$ of the respondents), service price $(86.18 \%$ of the respondents), while the level of profit ranked lowest $(66.82 \%$ of the respondents). When choosing a company, importance was attached to the company's reputation (72.35\%), although only $42.40 \%$ of the respondents are loyal to their insurance company. A total of $56.68 \%$ agreed that they feel more secure when they have an insurance policy. When choosing an insurance company, the company's location and appearance (office, staff, etc.) were least important, as claimed by $37.33 \%$ of the respondents.

The question "Which aspect of their work should insurance companies improve to increase quality?" was answered by $99.08 \%$ of the respondents, mainly with multiple answers. Most respondents circled the price of services offered by insurers $-63.59 \%$, then the salespeople's ability and knowledge $-50.23 \%$, and finally the procedure of processing and paying claims - 38.25\%. The price of insurance service had the greatest share in the total number of responses $-26.80 \%$; it was followed by the salespeople's ability and knowledge with $21.16 \%$, and the procedure of processing and paying claims with $16.12 \%$. The detailed overview with the number and percentage of each individual aspect of their work that insurance companies should improve to raise the quality of their business and the share of each aspect of work in total responses is provided in Table 4.

Table 4: Opportunities for increasing quality of insurance companies

\begin{tabular}{lcc}
\hline & $\begin{array}{c}\text { Number of } \\
\text { responses }\end{array}$ & Share of responses in \% \\
\hline Sales of insurance services & 20 & 3.88 \\
\hline Salespeople's ability and knowledge & 109 & 21.16 \\
\hline Kinds of services they offer & 43 & 8.35 \\
\hline Prices of services they offer & 138 & 26.80 \\
\hline Procedure of processing and paying claims & 83 & 16.12 \\
\hline Promotion of their services & 46 & 8.93 \\
\hline Distribution of their services & 23 & 4.47 \\
\hline Other & 53 & 10.29 \\
\hline Total number of responses & 515 & 100.00 \\
\hline
\end{tabular}

Source: Authors

\subsection{Frequency of responses}

Analysis of the frequency of responses was conducted using the descriptive statistics in the SPSS software. Table 5 provides the presentation of the frequency of responses, from the most to the least represented. As expected, the most represented (statistically significant) questions are those in the interval from 30 to 37 , which illustrate the components of the quality of operations and providing services to final users.

If we use the previously described 5P concept, it can be observed that the most significant/highest-rated element is the first one - purpose, which refers to client's security (question 32). The fourth element which, as we observed, is similar 


\section{Journal of Contemporary Management Issues}

to the first one, was also rated high, and it refers to the security and efficiency in paying the claim/insured amount (protection; question 35). They are followed by questions that can fall within categories, related to the personalization of service and partnership between the insured and the insurer (respect for the client, knowledgeable salespeople, accessibility of service, affordable price of the service, clear and good promotion of insurance services etc.). These results correlate with the results confirmed in economic literature relating to the $5 \mathrm{P}$ concept, which rate the elements of the fifth category as the most significant (from the user's aspect) when rating the relevance of insurance services (Zealley et al. 2018).

Table 5: Frequency of responses

$\begin{array}{lrlllll}\text { N } & \text { Mean } & \text { Std. } & \text { Skewness } & & \text { Kurtosis } & \text { Std. } \\ & \text { Dev. } & \text { Statistic } & \text { r } & \text { Statistic } & \text { Error }\end{array}$

32.When selecting an insurance service, I attach importance to security.

$\begin{array}{lllllll}217 & 4.81 & .471 & -2.447 & .165 & 5.354 & .329\end{array}$

35.Insurance companies should and efficiently.

\begin{tabular}{llllllll}
\hline $\begin{array}{l}\text { 34.Insurance companies should } \\
\text { treat clients with respect. }\end{array}$ & 217 & 4.78 & .478 & -2.089 & .165 & 3.673 & .329 \\
\hline $\begin{array}{l}\text { 37. Insurer's salespeople should } \\
\text { always be well- informed and } \\
\text { give clear answers to all my } \\
\text { questions. }\end{array}$ & 217 & 4.73 & .495 & -1.595 & .165 & 1.650 & .329 \\
\hline $\begin{array}{l}\text { 33.Promotion of insurance } \\
\text { services should be clear and } \\
\text { good. }\end{array}$ & 217 & 4.56 & .599 & -1.026 & .165 & .052 & .329 \\
\hline $\begin{array}{l}\text { 36.Insurance service should be } \\
\text { easily accessible. }\end{array}$ & 217 & 4.33 & .600 & -.280 & .165 & -.637 & .329 \\
\hline $\begin{array}{l}\text { 30.When choosing an insurance } \\
\text { service, I attach importance to } \\
\text { the price of service. }\end{array}$ & 217 & 4.16 & .737 & -.755 & .165 & .671 & .329 \\
\hline $\begin{array}{l}\text { 29.When choosing an insurance } \\
\text { company, I attach importance to } \\
\text { the company's reputation. }\end{array}$ & 217 & 3.83 & 1.064 & -.770 & .165 & -.280 & .329 \\
\hline $\begin{array}{l}\text { 31.When choosing an insurance } \\
\text { service, I attach importance to } \\
\text { the profit I gain. }\end{array}$ & 217 & 3.73 & 1.112 & -.792 & .165 & -.031 & .329 \\
\hline $\begin{array}{l}\text { 39.I feel more secure when I } \\
\text { have an insurance policy. }\end{array}$ & 217 & 3.52 & 1.187 & -.360 & .165 & -.967 & .329 \\
\hline $\begin{array}{l}\text { 20.I behave in accordance with } \\
\text { my religious beliefs. }\end{array}$ & 217 & 3.47 & .872 & -.310 & .165 & .080 & .329 \\
\hline
\end{tabular}




\begin{tabular}{lcccccccc}
\hline & $\mathrm{N}$ & Mean & $\begin{array}{c}\text { Std. } \\
\text { Dev. }\end{array}$ & $\begin{array}{l}\text { Skewness } \\
\text { Statistic }\end{array}$ & $\mathrm{r}$ & $\begin{array}{l}\text { Kurtosis } \\
\text { Statistic }\end{array}$ & $\begin{array}{l}\text { Std. } \\
\text { Error }\end{array}$ \\
$\begin{array}{l}\text { 38.I am loyal to my insurance } \\
\text { company. }\end{array}$ & 217 & 3.40 & 1.221 & -.057 & .165 & -1.065 & .329 \\
\hline $\begin{array}{l}\text { 13.Insurance services that are } \\
\text { offered are incomprehensible. }\end{array}$ & 217 & 3.04 & 1.327 & -.232 & .165 & -1.239 & .329 \\
\hline $\begin{array}{l}\text { 14.Insurance services are } \\
\text { expensive. }\end{array}$ & 217 & 3.04 & 1.327 & -.232 & .165 & -1.239 & .329 \\
\hline $\begin{array}{l}\text { 28. When choosing an insurance } \\
\text { company, I attach importance } \\
\text { to the company's location and } \\
\text { appearance (offices, staff, etc.). }\end{array}$ & 217 & 3.03 & 1.140 & .050 & .165 & -.909 & .329 \\
\hline $\begin{array}{l}\text { 12.Insurance companies do not } \\
\text { have a good relationship toward } \\
\text { insured persons. }\end{array}$ & 217 & 2.81 & 1.247 & .112 & .165 & -.600 & .329 \\
\hline $\begin{array}{l}\text { 11.Insurance companies are } \\
\text { institutions that cheat people. }\end{array}$ & 217 & 2.39 & 1.122 & .234 & .165 & -.879 & .329 \\
\hline $\begin{array}{l}\text { 15.Insurance services are } \\
\text { unnecessary in my daily life. }\end{array}$ & 217 & 2.18 & 1.093 & 1.098 & .165 & 3.025 & .329 \\
\hline \begin{tabular}{l} 
Valid N (listwise) \\
\hline
\end{tabular} & 217 & & & & & & \\
\hline \begin{tabular}{l} 
Source Authors' \\
\hline
\end{tabular}
\end{tabular}

Source: Authors' calculations

The use of Likert scale and descriptive statistics in the SPSS software reveals that security is a priority, when choosing an insurance company. This highlights the insurance companies' obligation to pay a particular attention to this factor. Other high-rated elements include fast and efficient payment of claims; salespeople's relationship to insured persons (salespeople's respect and knowledge), clarity of promotion and accessibility of insurance service. Security that results from holding an insurance policy and insured person's loyalty to the insurer are the reflections of insurer's relationship, adequacy of fulfilling/paying claims and monetary resources that (potential) insured persons have at their disposal.

Company's reputation also ranked high, and, therefore, a due attention should be paid to building trust. Price is a very important factor, as well as the possibility to gain profit and contractual obligations related to the payment of claim. Payment of claims is the basis of signing an insurance contract. The materialization of an insured event reveals facts about the insurer and their promise to pay the claim. The renewal of insurance contract and spreading a favourable word of mouth about the actual insurer depend on whether the insurer has lived up to the insured person's expectations.

\section{CONCLUSION}

Crucial success factors are skills, knowledge and resources that provide a company with competitive advantage. In the insurance industry, critical factors include service quality and client satisfaction, while the degree of service relevance can be assessed using the $5 \mathrm{P}$ concept, which, in turn, implies the achievement of five goals: 
purpose, pride, partnership, protection, and personalization, i.e., clients' security, satisfaction with the insurer's reputation, partnership, insured persons' protection and service personalization. The research in the $\mathrm{FBiH}$ revealed that the respondents highly valued these factors. However, the research also revealed that the population in $\mathrm{BiH}$ does not have sufficient knowledge of insurance, of its possibilities and significance, while financial literacy is insufficiently acknowledged and, therefore, a large number of the respondents do not feel more secure with the insurance policy, or do not have one.

The research limitation is related to the limited number of respondents, and the exclusive focus on insured persons and their perceptions of the quality and satisfaction with the service provided by insurance companies. Besides, processing and presentation of the results used the basic instruments of descriptive statistics. Future research should cover a bigger number of respondents, examine the views of both insured persons and salespeople and determine causal relations in views of these groups of respondents using inferential statistics.

\section{REFERENCES}

1. Alam, I. (2002). Selection of customers for involvement in the development of service innovations. Proceedings - Annual Meeting of the Decision Sciences Institute, San Diego, CA, United States. 23-26 November 2002.

2. Bader, M. A. (2008). Managing intellectual property in the financial services industry sector: Learning from Swiss Re. Technovation, 28(4), 196-207.

3. Barbir, V. (2004). Čimbenici uspješnosti prodaje usluga osiguranja. Ekonomski pregled, 55(9-10), 815-839.
4. Boynton, A. C \& Zmud, R. W. (1984). An assessment of critical success factors. Sloan Management Review, 25(4), 17-27.

5. Browne, M.T., \& Kim, K. (1993). An international analysis of life insurance demand. The Journal of Risk and Insurance, 60(4), 616-634.

6. Cata, T., \& Lee, S. M. (2006). Adoption of web-based applications in the financial Sector: The case of online insurance. Journal of Internet Commerce, 5(2), 41-61.

7. Chuwiruch, N., \& Ussahawanitchakit, P. (2013). Strategic relationship marketing leads to the success of insurance businesses in Thailand. International Journal of Business Research, 13(3), 85-100.

8. Cummins, J. D. (2005). Convergence in wholesale financial services: Reinsurance and investment banking. Geneva Papers on Risk and Insurance: Issues and Practice, 30(2), 187-222.

9. Daniel, D. R. (1961). Management Information Crisis. Harvard Business Review, 39(5), 111-116.

10. Farokhain, S., \& Sadeghi, T. (2011). Services quality model for online banking services by behavioral adoption theories and comparative study. African Journal of Business Management, 5(11), 4490-4499.

11. Eling, M., \& Kiesenbauer, D. (2012). Does surplus participation reflect market discipline? An analysis of the German life insurance market. Journal of Financial Services Research, 4 (3), 159-185.

12. Eesley, D.T., \& Adidam, P.T. (2012). Mavenness and salespeople success: An empirical investigation. Journal of Applied Business Research, 28(5), 903-912. 
13. Eccles, R.G., \& Vollbracht, M. (2006). Media reputation of the insurance industry: An urgent call for strategic communication management. Geneva Papers on Risk and Insurance: Issues and Practice, 31(3), 395-408.

14. Fjeldstad, Ø. D. \& Ketels, C. H. M. (2006). Competitive Advantage and the Value Network Configuration. Making Decisions at a Swedish Life Insurance Company. Long Range Planning, 39 (2), 109-131

15. Ghosh, B.C., Liang, T.W., Meng T.T. \& Chan, B. (2001). The key success factors, distinctive capabilities and strategies thrusts of top SMEs in Singapore. Journal of Business Research, 21, 209-221.

16. Grösch, M., \& Steul-Fischer, M. (2017). Defaults and advice in selfcustomization procedures of insurance. Zeitschrift für die gesamte Versicherungswissenschaft, 106 ( 3-4), 325-341.

17. Grunert, K.G.. \& Ellegaard, C. (1992). The Concept of KSF: Theory and Method in: Baker, M. (Ed). Perspectives of Marketing Management. Chichester: Wiley, 245-274.

18. Hamdi, K., \& Zamiri, A. (2016). Identifying and segmenting customers of pasargad insurance company through RFM model (RFM). International Business Management, 10(18), 4209-4214.

19. Joshi, H., Farooquie, J. A., \& Chawla, D. (2016). Use of Knowledge Management for Competitive Advantage: The Case Study of Max Life Insurance. Global Business Review, 17(2), 450-469.

20. Klasić, K. (2003). Utjecaj psihologije pojedinca na izbor vrsta osiguranja. Ekonomski pregled, 54(7-8), 595-620.
21. Kreuzer, T, Röglinger, M., \& Rupprecht, L. (2020). Customer-centric prioritization of process improvement projects, Decision Support Systems, 133,113286

22. Lewis, F. D. (1989). Dependents and the demand for life insurance. The American Economic Review, 79(3), 452-467.

23. Li, D., Moshirian, F., Nguyen, P., \& Wee, T. (2007). The demand for life insurance in OECD countries. The Journal of Risk and Insurance, 74(3), 637-652.

24. Lorson, J., \& Wagner, J. (2014). Sales Efficiency in Life Insurance: The Drivers for Growth in the German Market. The Geneva Papers on Risk and Insurance - Issues and Practice, 39, 493-524.

25. Mahlow, N,. \& Wagner, J. (2016). Evolution of Strategic Levers in Insurance Claims Management: An Industry Survey. Risk Management and Insurance Review, 19(2), 197-223.

26. Manna, D.R., \& Smith, A. D. (2004). Exploring the need for emotional intelligence and awareness among sales representatives. Marketing Intelligence \& Planning, 22(1), 66-83.

27. Mantis, G., \& Farmer, R. N. (1968). Demand for life insurance, The Journal of Risk and Insurance, 35(2), 247-256.

28. Mitra, A., Gaur, S. S., \& Giacosa, E. (2019). Combining organizational change management and organizational ambidexterity using data transformation. Management Decision, 57(8), 2069-2091.

29. Oduniyi, O.S., Antwi, M. A., \& Tekana, S. S. (2020). Farmers' willingness to pay for index-based livestock insurance in the North West of South Africa, Climate, 8(3), 47. 
30. Rajapathirana, R. P. J., \& Hui, Y. (2018). Relationship between innovation capability, innovation type, and firm performance. Journal of Innovation and Knowledge, 3(1), 44-55.

31. Ranani, G. A.. \& Arastoo, I. (2006). The relationship between emotional intelligence and transformational leadership in insurance top managers in Iran. Academic Leadership, 4 (4)

32. Rockart, J.F. (1979). Chief Executive Define Their Own Information needs. Harvard Business Review. March/ April, 81-92.

33. Rockart, J.F. \& Bullen, C. V. (1981). A primer on Critical Success Factors. MIT, Sloan School of Management. Massachusetts, USA.

34. Röschmann, Z. (2018). Digital insurance brokers - old wine in new bottles? How digital brokers create value. Zeitschrift für die gesamte Versicherungswissenschaft, 107(3), 273-291.

35. Sanvido, V., Grobler, F., Pariff, K., Guvents, M., \& Coyle, M. (1992). Critical success factors for construction projects. Journal of Construction Engineering and Management, 118(1), 98-111.

36. Shahsiah, N., \& Sepahvand, R. (2016). Studying the mediating role of knowledge sharing and market orientation to enhance the intellectual capital effect on the organizational innovation (supervision of insurance companies in Lorestan Province). International
Business Management, $10 \quad$ (20), 4776-4782.

37. Srivastava, V., Mahanty, A. K., \& Pandey, S. K. (2020). Determinants of organizational success: An empirical analysis of insurance sector in India. International Journal of Advanced Science and Technology, 29(5), 1689-1707

38. Toor, S.R., \& Ogunlana, S.O. (2009). Construction professional's perception of critical success factors for large-scale construction projects. Construction Innovation, 9(4), 149-167.

39. Trautinger, M. J. (2018). Kundenzufriedenheit als Steureungsinstrument in einem Versicherungsunternehmen. Nur Schall und Rauch oder ökonomisch sinnvoll? Zeitschrift für die gesamte Versicherungswissenschaft, 107(1), 3-39.

40. Yang, B., Kim, Y., \& McFarland, R. G. (2011). Individual differences and sales performance: A distal-proximal mediation model of self-efficacy, conscientiousness, and extraversion. Journal of Personal Selling and Sales Management, 31(4), 371-381.

41. Zealley, J., Wollan, R., \& Bellin, J. (2018). Marketers Need to Stop Focusing on Loyalty and Start Thinking About Relevance. Harvard Business Review. https://hbr. org/2018/03/marketers-need-to-stopfocusing-on-loyalty-and-start-thinkingabout-relevance 


\section{KRITIČNI ČIMBENICI USPJEHA DRUŠTAVA ZA OSIGURANJE}

Sažetak. Tema ovog rada su kritični čimbenici uspjeha, s fokusom na društva za osiguranje. Ne postoje kritični čimbenici uspjeha zajednički za sva poduzeća, područja i aktivnosti. $U$ društvima za osiguranje, oni prvenstveno ovise o kvalitetu usluge te razini zadovoljstva korisnika. U suvremenim uvjetima poslovanja, poseban se značaj pridaje usluzi. Stoga se predlaže korištenje koncepta 5P, cije su sastavnice svrha poslovanja (purpose, engl.), ponos, partnerstvo, sigurnost/zaštita (protection, engl.) te personalizacija, kao čimbenici, koji određuju zahtjeve, potrebne za percepciju usluge društva za osiguranje kao visoko kvalitetnog, ali i za postizanje zadovoljstva te izgradnju lojalnosti klijenata. U radu se predstavljaju rezultati istraživanja percepcije osiguravateljne usluge te čimbenici postizanja kvalitete osiguranja u entitetu Federacije Bosne $i$ Hercegovine (FBiH). Rezultati istraživanja odgovaraju konceptu 5P te otkrivaju čimbenik sigurnosti kao najznačajniji za osiguranike. Brza i učinkovita isplata šteta, stav prodajnog osoblja prema osiguranicima, koji se može opisati u terminima poštovanja i poznavanja poslovne problematike, kao i jasnoća promocije te dostupnost osiguravateljne usluge, također su se plasirali na visoke pozicije u istraživanju.

Ključne riječi: kritični čimbenici uspjeha, društva za osiguranje; koncept $5 P$ 